\title{
Sand failure: effect of biocide on the geomechanical properties of outcrop carbonate rock under static condition
}

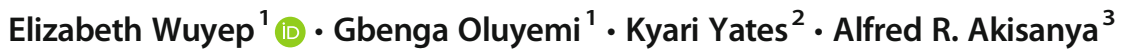

Received: 14 July 2019 / Accepted: 26 October 2020 / Published online: 19 November 2020

(C) The Author(s) 2020

\begin{abstract}
The effects of chemical interaction of a biocide with formation rocks on the rock geomechanical properties are examined. A combination of analytical tests (scanning electron microscopy/energy-dispersive X-ray analysis, X-ray powder diffraction and particle size distribution) and uniaxial compression test was used in this study. The particle size distribution in the effluent showed an increase in $D_{50}$ with poor sorting for the chemically treated outcrop carbonate core samples. The XRPD shows evidence of altered minerals in the chemically treated samples. It was observed that the interaction led to precipitation of new materials that clogged the pore space of the samples leading to up to $150 \%$ increase in compressive strength of the carbonate following treatment with the biocide. The results give more insight into the limitations of existing sand production prediction models with respect to the effect of oilfield chemicals on the strength of the reservoir rocks.
\end{abstract}

Keywords Chemical interaction $\cdot$ Glutaraldehyde $\cdot$ Dolomite $\cdot$ Uniaxial compressive strength $\cdot$ Reservoir rock

\section{Introduction}

Biocides are typically used in oil and gas industry to control the activities of undesirable bacteria and microorganisms that produce some substances, such as $\mathrm{H}_{2} \mathrm{~S}$ and organic acids, which can cause corrosion of production tubulars, casings and facilities. Unfortunately, the deleterious effect of the interaction of the biocide with the reservoir rock has not always been accounted for nor widely studied. The interaction of chemicals with the reservoir rocks under static condition has not been widely published. Seto et al. (1997) examined the effect of polyethylene oxide (PEO), aluminium chloride $\left(\mathrm{AlCl}_{3}\right)$ and

This paper was selected from the 1st Conference of the Arabian Journal of Geosciences (CAJG), Tunisia 2018

Responsible Editor: Amjad Kallel

Elizabeth Wuyep

ewuyep@yahoo.com

1 School of Engineering, Robert Gordon University, Aberdeen AB10 7GJ, UK

2 School of Pharmacy and Life Science, Robert Gordon University, Aberdeen AB10 7GJ, UK

3 School of Engineering, University of Aberdeen, Aberdeen AB24 3UE, UK dodecyltrimethylammonium bromide (DTAB) on sandstone under static condition to establish fundamental knowledge for chemically assisted fracturing. It was found that these chemicals did not cause any significant change in the compressive strength of the sandstone. The chemistry and composition of the chemicals used in the work are different from those of biocide and other commonly used oilfield chemicals. Wuyep et al. (2018) investigated the effect of a scale inhibitor (amino trimethylene phosphonic acid) ATMP, a biocide (glutaraldehyde) and a corrosion inhibitor (betaine) on the strength of reservoir rocks under static condition to quantify the effects of these chemicals on sand failure. This current work further explores the deleterious effect of a biocide on the geomechanical strength of outcrop carbonate rock with a view to drawing comparison if any, between the effects of the chemical on carbonate reservoir rocks and outcrop samples under static condition.

\section{Materials and method}

The biocide used in this study is glutaraldehyde $\left(\mathrm{C}_{5} \mathrm{H}_{8} \mathrm{O}_{2}\right)$, and it was obtained from REDA Oilfield UK. $\mathrm{Ltd}^{1}$, whilst a

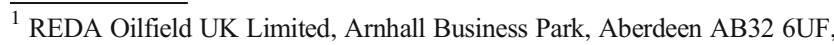
UK (www.redaoilfield.com)
} 
synthetic brine with the composition shown in Table 1 was used as control. Four (4) cylindrical outcrop core samples with a diameter of $38 \mathrm{~mm}$ and length of $51 \mathrm{~mm}$ obtained from Texas, USA, through Kocurek Industries Ltd were the substrates.

\section{Static saturation}

The saturation was done by putting each core sample in three separate beakers and filling two of the beakers with $1 \mathrm{wt} \%$ glutaraldehyde well enough to cover the cores. In a similar manner, the third beaker was filled with the brine well enough to cover the core. The setup was left to stay with a lid for 7 days to ensure complete saturation. The cores were removed from the fluids after 7 days, aired and oven dried at $106{ }^{\circ} \mathrm{C}$ and then prepared for mechanical testing, SEM/EDX and XRPD analyses. The effluents from the core saturation were analysed for particle size distribution, $\mathrm{pH}$ and cation concentration $\left(\mathrm{Ca}^{2+}, \mathrm{Na}^{+}\right.$and $\mathrm{Mg}^{2+}$ ) by ICP-OES. Full details of the procedures for the brine and chemical preparation, analyses as well as saturation detail can be found in Wuyep et al. (2018) and Oluyemi (2014).

\section{Mechanical testing, SEM/EDX and XRPD analyses}

Uniaxial compression test was performed on both untreated and chemically treated rock samples to determine the strength of the rock pre- and postchemical treatment. The length to diameter ratio of the cores was 1.3 which is lower than the standard ratio of $2-$ 2.5. As such, the strengths were corrected using the strength correction factors of 0.93 suggested by ASTM (1991) and 0.87 suggested by BS 1881, part 120. Scanning electron microscopy (SEM), energy-dispersive $\mathrm{X}$-ray (EDX) and X-ray powder diffraction analyses (XRPD) were carried out to evaluate the morphology, elemental and mineralogical composition of the rock samples before and after chemical treatment. Details of the analytical procedures can be found in Wuyep et al. (2018). Particle size distribution analysis of the effluents from the core treatment was also conducted using a Malvern Mastersizer S.

\section{Results and discussion}

\section{Evaluation of elemental and mineralogical composition of the rock sample}

A cross section of untreated carbonate (Edward brown) under SEM (Fig. 1a) revealed dolomitized limestone with moderately sorted euhedral-subhedral dolomite $\left(\mathrm{CaMg}\left(\mathrm{CO}_{3}\right)_{2}\right)$ mineral with sucrosic texture (Wuyep et al. 2020). Observed in the SEM micrograph were cloudy centres and light rims which are typical of dolomites (dotted spheres in Fig. 1a). The dolomite grains are coated with pore filling calcite and authigenic clay minerals (Fig. 1a, b, c). Several interconnected pore spaces shown as ' $\mathrm{P}$ ' in Fig. 1a are observed in the sample. The EDX spectrum (Fig. 1d) indicates the presence of $\mathrm{Mg}$ (5.79 wt\%), C (5.16 wt\%), O (70.20 wt\%) and $\mathrm{Ca}(10.88$ $\mathrm{wt} \%)$ which is typical of dolomitic carbonate. Other elements observed in the sample are $\mathrm{Al}(2.20 \mathrm{wt} \%) \mathrm{K}(0.65 \mathrm{wt} \%), \mathrm{Cl}$ (0.44 wt \%), $\mathrm{Si}(4.30 \mathrm{wt} \%)$ and $\mathrm{Fe}(0.38 \mathrm{wt} \%)$. The presence of $\mathrm{Al}, \mathrm{K}, \mathrm{Si}, \mathrm{Ca}$ and $\mathrm{Mg}$ typifies illite, kaolinite and mixed-layer illite/smectite content. The presence of $\mathrm{Cl}$ is an indication that the sample contains halite, whilst the Fe content indicates the presence of pyrite in the sample.

XRPD whole rock analysis of the untreated carbonate (Fig. 2a) further confirms the presence of dolomite $(73.8 \mathrm{wt} \%)$, calcite $(21.2 \mathrm{wt} \%)$, quartz $(3.7 \mathrm{wt} \%)$, pyrite $(0.2 \mathrm{wt} \%)$, halite $(0.2 \mathrm{wt} \%)$ and multi-layer illite/smectite $(0.9 \mathrm{wt} \%)$. Clay fraction analysis with XRPD (Fig. 2b) confirms the presence of kaolinite $(7 \%)$, illite $(7 \%)$ and multi-layer illite/smectite $(86 \%)$.

On the other hand, the SEM micrograph (Fig. 3a) shows the brine-treated carbonate to have about $50 \%$ of the pore spaces filled with the precipitated materials which are believed to have originated from the dissolution and precipitation reactions that took place during the interaction of the rock and the brine. Meanwhile, the SEM of the glutaraldehyde treated carbonate shows that over $90 \%$ pore spaces were filled with precipitates (Fig. 3b). EDX spectrum (Fig. 3c) reveals that the brine-treated sample also contains $\mathrm{Ca}(17.09 \mathrm{wt} \%), \mathrm{Mg}$ (6.59 wt \%), C (3.95 wt\%), Na (1.20 wt\%), O (63.13 wt\%), Al (1.25 wt \%), Si (3.73 wt\%), Cl (2.02 wt\%), K (0.48 wt \%) and Fe $(0.56 \mathrm{wt} \%)$. Similarly, EDX scan (Fig. 3d) indicates the presence of $\mathrm{Ca}(17.16 \mathrm{wt} \%), \mathrm{O}(67.74 \mathrm{wt} \%), \mathrm{Mg}(6.40 \mathrm{wt} \%)$, $\mathrm{Al}(1.16 \mathrm{wt} \%), \mathrm{C}(2.90 \mathrm{wt} \%), \mathrm{Si}(3.19 \mathrm{wt} \%), \mathrm{K}(0.54 \mathrm{wt} \%), \mathrm{Fe}$ $(0.60 \mathrm{wt} \%)$ and $\mathrm{Cl}(0.31 \mathrm{wt} \%)$ in the glutaraldehyde treated
Table 1 Brine composition (modified after Jordan and Sjursaether 2005, Vazquez et al. 2016)

\begin{tabular}{llllllllll}
\hline Element & $\mathrm{Na}^{+}$ & $\mathrm{K}^{+}$ & $\mathrm{Ca}^{2+}$ & $\mathrm{Mg}^{2+}$ & $\mathrm{Ba}^{2+}$ & $\mathrm{Sr}^{2+}$ & $\mathrm{Cl}^{-}$ & $\mathrm{SO}_{4}{ }^{2}$ & $\mathrm{HCO}_{3}{ }^{2}$ \\
\hline Concentration (ppm) & 24870 & 887 & 785 & 561 & 108 & 3 & 39800 & 35 & 2014 \\
\hline
\end{tabular}


Fig. 1 Characterization of untreated carbonate: $\mathbf{a}, \mathbf{b}, \mathbf{c}$ using SEM at different magnifications and $\mathbf{d}$ EDX spectrum showing the elemental content and peaks

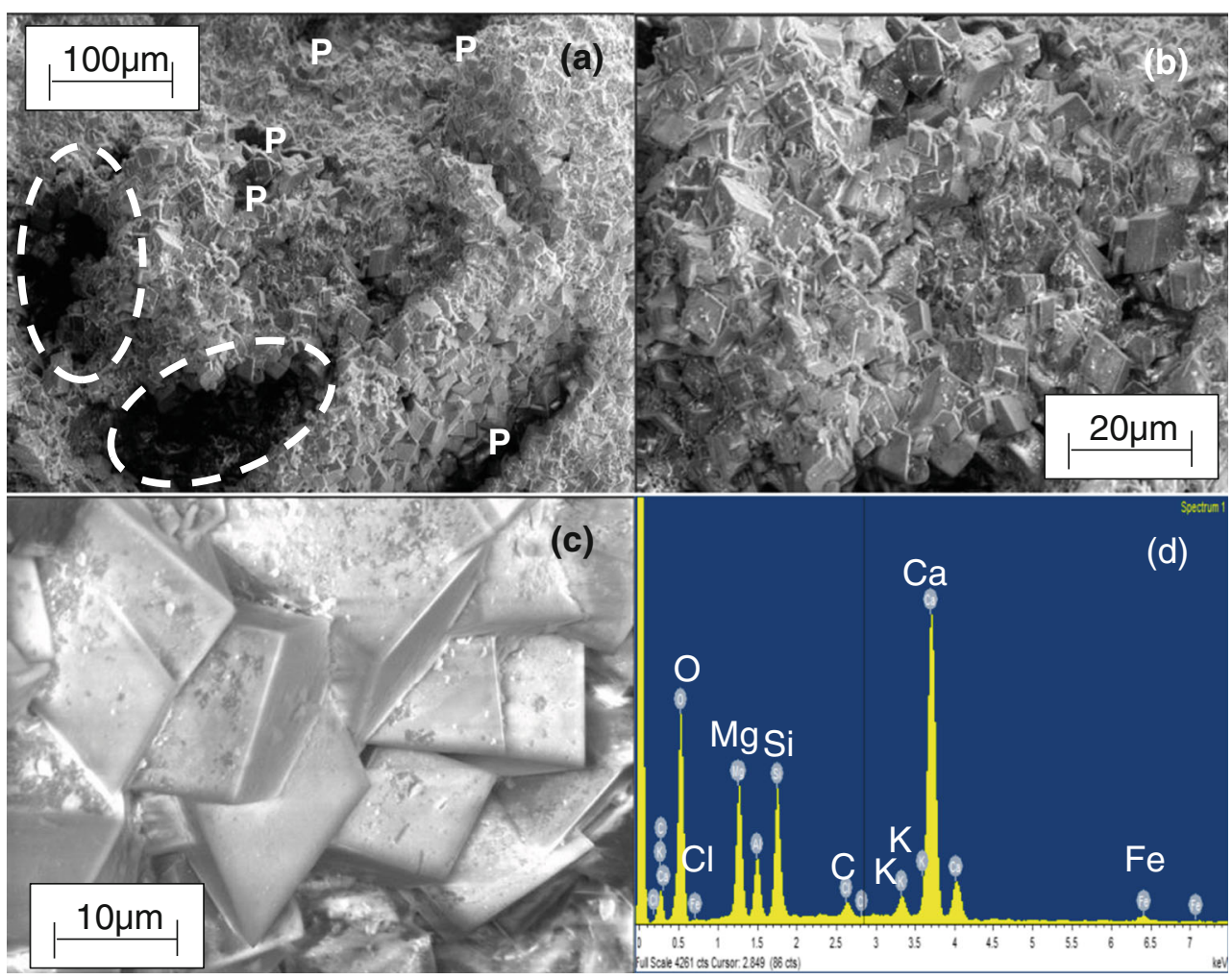

carbonate. The $58 \%$ and $11 \%$ increase in $\mathrm{Ca}$ and $\mathrm{Mg}$ contents respectively in the glutaraldehyde and brine-treated samples might have originated from the interaction between the fluids and the rock.

The increase in weight per cent of the key elements (Ca and $\mathrm{Mg}$ ) observed under EDX was confirmed by the increase in weight percent of dolomite from 73.8 to 92.6 and 95.1 in the presence of brine and glutaraldehyde respectively under XRPD (Fig. 4). This suggests precipitation reaction. In the same manner, dissolution reaction was suggested by the reduction in the weight percent of calcite from 21.2 to 2.3 and $1.6 \%$ following treatment with brine and glutaraldehyde respectively. The clay fraction (Fig. 4b) shows little or no change with the clay minerals content (kaolinite, illite and mixed-layered illite-smectite) when exposed to brine and glutaraldehyde.

Comparing the results of characterisation of the untreated carbonate with the chemically treated carbonate, it is obvious that there is a change in the weight per cent of the elements ( $\mathrm{Ca}$ and $\mathrm{Mg}$ ) and minerals (dolomite and calcite) composition of the brine-treated carbonate. This is contrary to the general belief that formation brine is in equilibrium with the formation rock in their natural environment and only destabilises/ disequilibrates in the presence of external forces (Fjaer et al. 2008). However, the reason for the contrast could be attributed to the fact that the brine is synthetic, and the core samples were outcrop.

The $\mathrm{pH}$ of glutaraldehyde solution and the brine were 7.5 and 7 respectively before the core sample saturation process
Fig. 2 XRPD analysis of untreated carbonate. a Bulk mineralogical. b Clay fraction

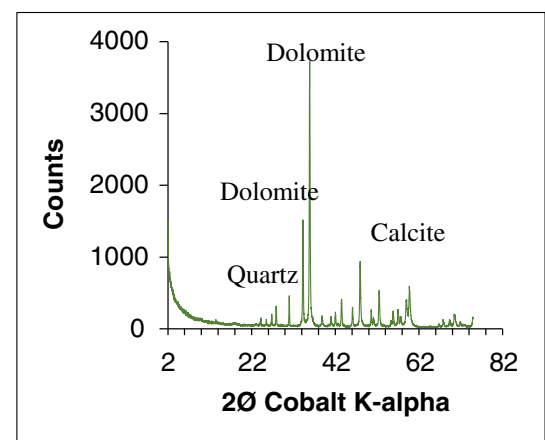

(a)

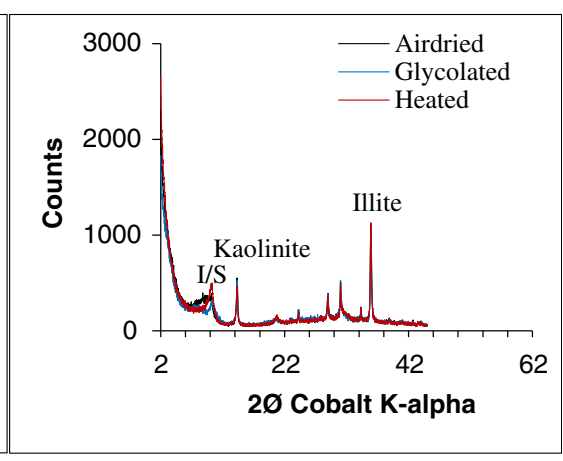

(b) 

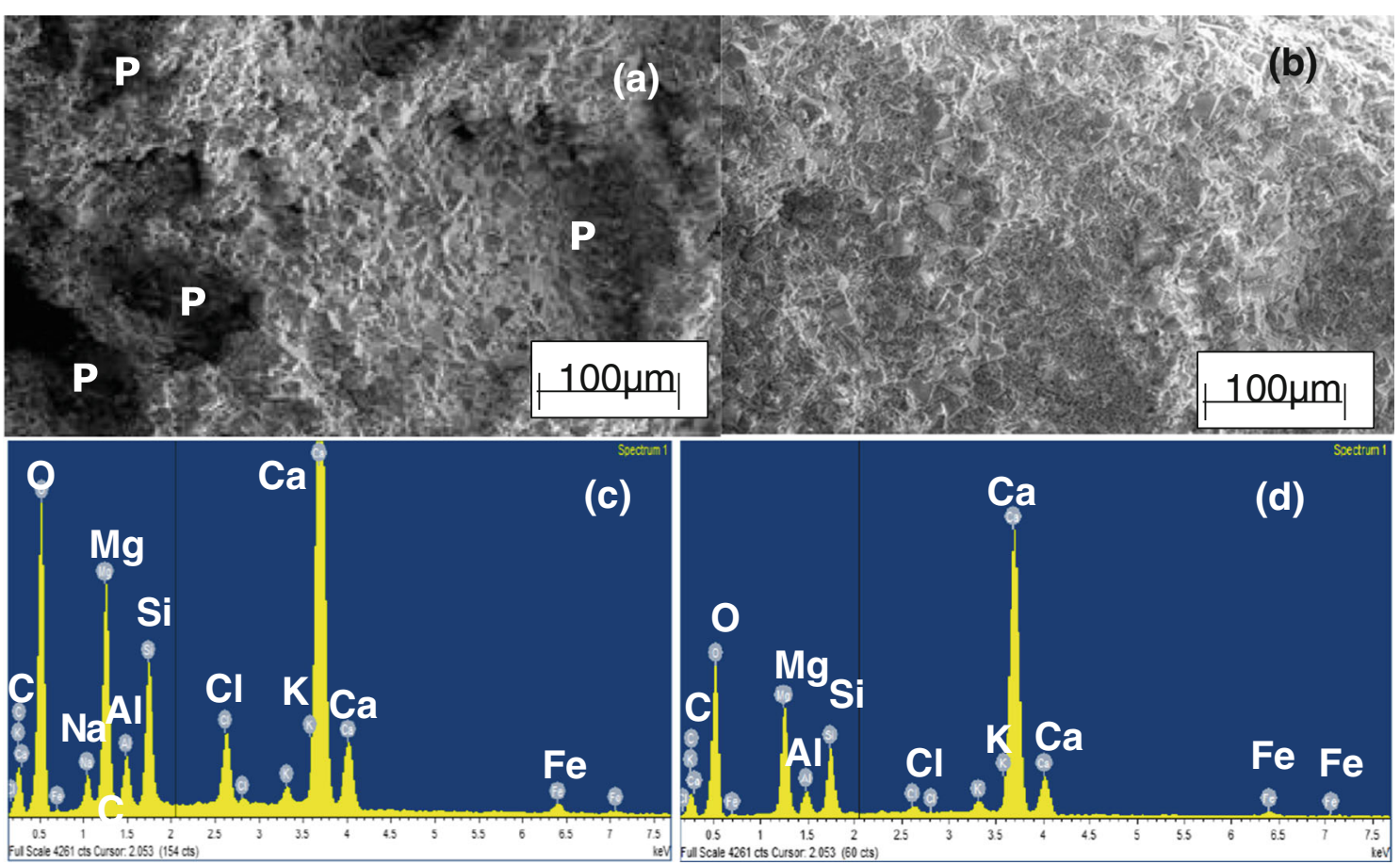

Fig. 3 The SEM micrographs of the carbonate treated with a brine, $\mathbf{b}$ glutaraldehyde, and the corresponding EDX spectrum for the carbonate treated with $\mathbf{c}$ brine and $\mathbf{d}$ glutaraldehyde

and the $\mathrm{pH}$ remained unchanged after the saturation. According to Karsa (2007), glutaraldehyde has increased activity at a $\mathrm{pH}$ higher than 7.3; hence, the precipitation of carbonate minerals may have been made possible by the production of alkalinity which could be due to sulphate reduction (Meister 2013 \& Morse et al. 2007).

The analysis of the effluents showed changes in concentration of $\mathrm{Na}^{+}, \mathrm{Ca}^{2+}$ and $\mathrm{Mg}^{2+}$. There was a $72 \%$ and
$6 \%$ increase in $\mathrm{Na}^{+}$and $\mathrm{Ca}^{2+}$ concentration in brine effluent respectively, whilst the effluent of glutaraldehyde showed $65 \%$ and $35 \%$ decrease in the $\mathrm{Na}^{+}$and $\mathrm{Ca}^{2+}$ concentration respectively. $\mathrm{Mg}^{2+}$ was observed to have increased by $25 \%$ and $19 \%$ in brine and glutaraldehyde effluents respectively. This is an indication that $\mathrm{Na}^{+}$and $\mathrm{Ca}^{2+}$ were adsorbed by the rock, whilst $\mathrm{Mg}^{2+}$ was released into the effluents.
Fig. 4 Bulk mineralogy (weight $\%$ ) and clay fraction characterisation of treated carbonate: a brine, XRPD; b brine, clay fraction; $\mathbf{c}$ Glutaraldehyde (XRPD); d glutaraldehyde, clay fraction

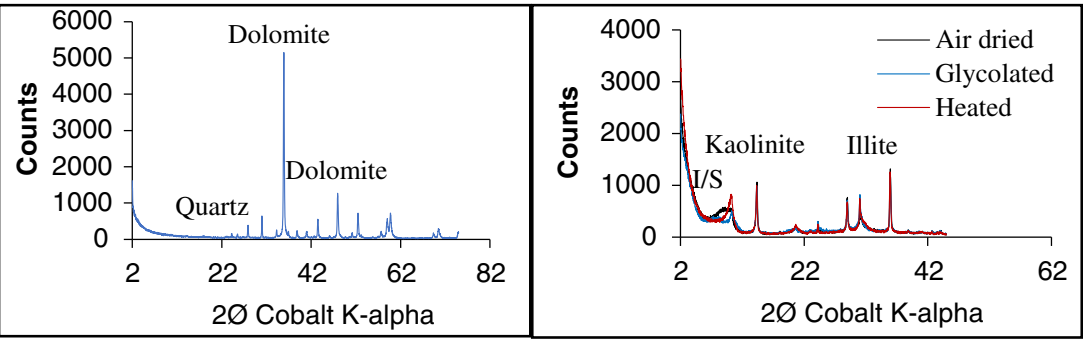

(a)

(b)

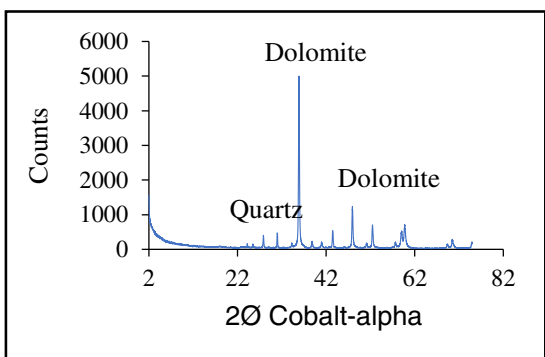

(c)

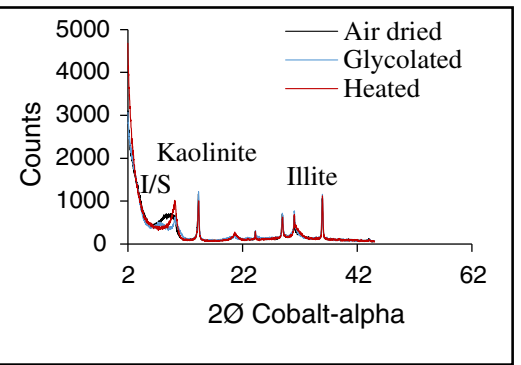

(d) 
Table 2 Grain size distribution with sorting of the original brine and the effluents based on Folk (1966) classification

\begin{tabular}{lllllll}
\hline Effluents & \multicolumn{2}{l}{ Particle size $(\mu \mathrm{m})$} & & \multicolumn{2}{l}{ Classification } \\
\cline { 2 - 3 } \cline { 6 - 7 } Limestone & $D_{10}$ & $D_{50}$ & $D_{90}$ & & Sorting $(\sigma 1)$ & Description \\
\hline Original brine & 3 & 7 & 30 & & 0.01 & Very well sorted \\
Carb-Brine & 2 & 15 & 41 & & 0.54 & Moderately sorted \\
Carb-Glut 1 & 7 & 70 & 407 & & 0.84 & Moderately sorted \\
Carb-Glut 2 & 7 & 71 & 408 & & 0.85 & Moderately sorted \\
\hline
\end{tabular}

The analytical results have shown that the interaction between glutaraldehyde and the carbonates as well as the interaction between the brine and the carbonates can lead to precipitation of new materials that fill the pore spaces (pore clogging). Apart from the fact that the pore clogging due to precipitation causes formation damage, there is the danger that it could lead to hydrocarbon production impairment. It is noteworthy that there are instances where the precipitated materials that fill the pore spaces may not be as strongly cemented as in their original state. This can cause grain fabric weakening which may lead to rock failure (Wuyep et al. 2018, 2020). XRPD further confirms the preponderance of dolomite $(95.1 \mathrm{wt} \%)$ in the carbonate. The change in weight percent of calcite and dolomite supports the view of dissolution/precipitation reaction as discussed earlier. According to existing literature (Plummer et al. 1978), three simultaneous reaction mechanisms are identified with calcite dissolution process. Thus, in this work, the likely reactions involving the calcite dissolution and dolomite precipitation when the rock is exposed to brine and glutaraldehyde are the following:

$$
\begin{aligned}
& \mathrm{CaCO}_{3} \longleftrightarrow{ }^{+} \mathrm{Ca}^{2+}+\mathrm{HCO}_{3}^{-} \\
& \mathrm{CaCO}_{3}+\mathrm{H}_{2} \mathrm{CO}_{3}^{0} \leftrightarrow 2 \mathrm{HCO}_{3}^{-} \\
& \mathrm{CaCO}_{3}+\mathrm{H}_{2} \mathrm{O} \leftrightarrow \mathrm{Ca}^{2+} \mathrm{HCO}_{3}^{-}+\mathrm{OH}^{-} \\
& \mathrm{Ca}^{2+}+\mathrm{Mg}^{2+}+2 \mathrm{C}^{+} 6 \mathrm{O}^{-} \longleftrightarrow^{2 \mathrm{H}^{+}} \mathrm{CaMg}\left(\mathrm{CO}_{3}\right)_{2}
\end{aligned}
$$

Based on Eqs. (2) and (3), the rate equation that accounts for the dissolution and precipitation under ambient temperature was formulated as follows:

$$
r=\underbrace{k_{1}\left[\mathrm{H}_{2} \mathrm{CO}_{3}^{0}\right]}_{r_{f w}}-\underbrace{k_{3}\left[\mathrm{HCO}_{3}^{-}\right]\left[\mathrm{Ca}^{2+} \mathrm{HCO}_{3}^{-}\right]}_{r_{b}}
$$

where $r$ is the specific rate of calcite dissolution $\left(\mathrm{mol} / \mathrm{m}^{3} / \mathrm{s}\right)$, separated in a forward rate $r_{f w}$ and precipitation in a backward rate $r_{b}$ and $k_{1}, k_{2}, k_{3}$ are the rate constants.

\section{Grain size distribution analysis}

Figure 5 a shows a slight difference in shape and key parameters between the grain size distribution profiles of the original brine and the brine effluents from the carbonates. This is consistent with the visual observation of the effluents. The $D_{10}, D_{50}$ and $D_{90}$ values for the original brine and the brine effluents (Table 2) from the carbonates were generally $<45 \mu \mathrm{m}$. On the other hand, the $D_{10}, D_{50}$ and $D_{90}$ values for the glutaraldehyde effluents from carbonate increased remarkably (by a factor of 10) relative to those of brine. The increase suggests that some reactions such as dissolution/precipitation orchestrated by diffusion and adsorption might have taken place between the chemical and the rock samples that led to deterioration of the grain to grain binding resulting in grains detachment and release into the fluid stream. The result is consistent with earlier work by Wuyep et al. (2018) and Oluyemi (2014).

\section{Effect of exposure to chemical on compressive strength and Young's modulus}

Figure 6 a shows an increase in the compressive strength of the carbonate (Edward brown) from 5.6 MPa when untreated to 8.4 and $12.1 \mathrm{MPa}$ owing to treatment with brine and glutaraldehyde respectively. The $50 \%$ and $100 \%$ increase in strength of carbonate post-treatment with brine and
Fig. 5 Grain size distribution profiles of a original brine and brine effluent from carbonate and b brine effluent and glutaraldehyde effluent from carbonate

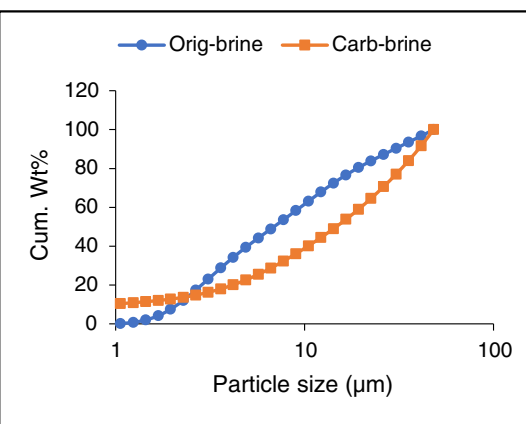

(a)

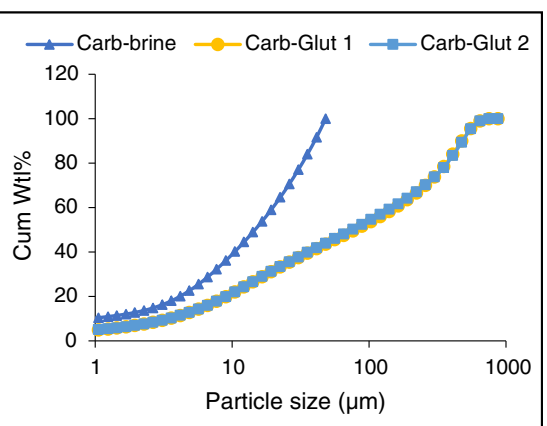

(b) 
Fig. 6 Stress-strain relationship of untreated and chemically treated Edward brown carbonate. a Complete response to failure. $\mathbf{b}$ Stress-small strain response

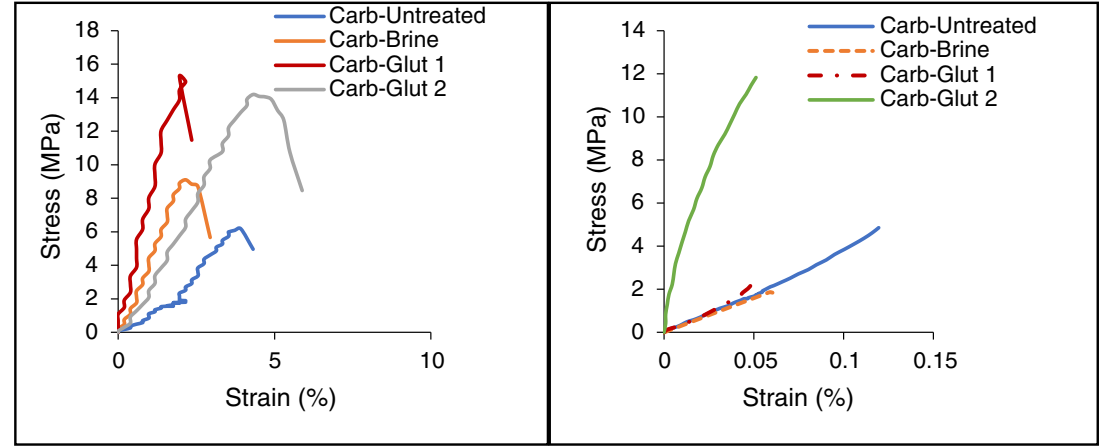

(a)

(b) glutaraldehyde confirms the pore space filling by the precipitated materials which was made possible by the dissolution/ precipitation reaction. However, the determined strength of untreated carbonate (Edward brown) is outside the range of declared strength (14-21 MPa) by Kocurek Industries Ltd. The increase in strength results from the precipitates filling the pore space, the phenomenon called pore clogging. Unfortunately, there is danger of formation damage and formation fluids production impediment with pore clogging. The result is contrary to the weakening effect of chemical activity of the pore water on chalk reported by Risnes et al. (2003).

The measured Young's modulus, $E$, of carbonate from the test results shows an increase in the modulus from 4 to $11 \mathrm{GPa}$ following treatment with glutaraldehyde and insignificant change for brine-treated sample which has a modulus of 5 GPa (Fig. 6b). The measured values of the modulus for the untreated, brine and glutaraldehyde treated rock samples are within the typical range of Young's modulus for carbonates (3-27 GPa).

\section{Conclusions}

The effect of the interaction of biocide with the Edward Brown carbonate rock analogous to reservoir rock has been investigated under ambient and static conditions. Both untreated and chemically treated rock samples were characterised using analytical and mechanical tests. The results show that chemical reactions, namely, diffusion, adsorption, dissolution and precipitation took place which led to release of materials and filling of pore spaces with the new materials. The overall results suggest the predominance of precipitation reaction. The interaction between biocide and carbonate rock led to precipitation of new materials that fill the pore spaces giving a false strength which can be reduced under a prevailing condition. The pore filling can lead to formation damage and hydrocarbon production impediment. It is worthy of note that the cementing of the precipitated materials that fill the pore spaces may not be as strong as the original cement material, thus can lead to grain fabric weakening and hence decrease geomechanical strength.

It is important that the field operators factor the pore clogging potential and grain fabric weakening effects of the biocide in the evaluation of rock failure/damage program for production optimization.

Funding The authors received funding from the Petroleum Technology Development Fund (PTDF), Nigeria, for the $\mathrm{PhD}$ work from which the materials and results presented in this paper originated.

Open Access This article is licensed under a Creative Commons Attribution 4.0 International License, which permits use, sharing, adaptation, distribution and reproduction in any medium or format, as long as you give appropriate credit to the original author(s) and the source, provide a link to the Creative Commons licence, and indicate if changes were made. The images or other third party material in this article are included in the article's Creative Commons licence, unless indicated otherwise in a credit line to the material. If material is not included in the article's Creative Commons licence and your intended use is not permitted by statutory regulation or exceeds the permitted use, you will need to obtain permission directly from the copyright holder. To view a copy of this licence, visit http://creativecommons.org/licenses/by/4.0/.

\section{References}

ASTM. Standard test method for obtaining and testing method for obtaining and testing drilled cores and sawed beams of concrete (1991) Annual Book of ASTM Standards. Concr Aggregates 4(C): 42-90

Fjaer E, Holt RM, Horsrud P, Raaen AM, Risnes R (2008) Chapter 2 Failure mechanics. In: Developments in Petroleum Science, vol 53, pp 55-102

Folk RL (1966) A review of grain-size parameters. Sedimentology 6(2): 73-93

Jordan MM, Sjursaether K (2005) Scale control within sea chalk/ limestone reservoirs. The challenge of understanding and optimizing chemical placement methods and retention mechanism: laboratory to field. Paper Presented at the SPE International Symposium and Exhibition on Formation Damage Control, Lafayette, Louisiana, USA. 18-20 February 
Karsa D (2007) Biocide. In: Handbook for cleaning/decontamination of surfaces, vol 1, pp 593-623. https://doi.org/10.1016/B978044451664-0/50018-8

Meister P (2013) Two opposing effects of sulfate reduction on carbonate precipitation in normal marine, hypersaline, and alkaline environments. Geology. 41(4):499-502

Morse J, Arvidson R, Luttge A (2007) Calcium formation and dissolution. Chem Rev 107(2):342-381

Oluyemi GF (2014) Conceptual physicochemical models for scale inhibitor-formation rock. Int Pet Sci Tech 32(3):253-260

Plummer LN, Wigley TML, Parkhurst DL (1978) The kinetics of calcite dissolution in $\mathrm{CO} 2$-water systems at 5 degrees to 60 degrees $\mathrm{C}$ and 0.0 to $1.0 \mathrm{~atm} \mathrm{CO} 2$. Am J Sci 278(2):179-216
Risnes R, Haghighi H, Korsnes RI, Natvik O (2003) Chalk-fluid interactions with glycol and brines. Technophysics 370:213-226

Seto M, Nag DK, Vutukuri VS, Katsuyyama K (1997) Effect of chemical additives on the strength of sandstone. Int J Rock Mech Min Sci 34: 3-4

Vazquez O, Herrero P, Mackay E, Jordan M (2016) Non-aqueous overflush scale inhibitor squeeze treatment in an oilfield offshore Norway. J Pet Sci Eng 138:1-10

Wuyep EO, Oluyemi GF, Yates K, Akisanya AR (2018) Geomechanical effects of oilfield chemicals on sand failure in reservoir rocks. J Pet Sci Eng 165:347-357

Wuyep EO, Oluyemi GF, Yates K, Akisanya AR (2020) Evaluation of the interaction between oilfield chemicals and reservoir rocks. Nat Resour Res 29(2):1239-1259 